\title{
In-Cell Assembly of scFv from Human Thyroid- Infiltrating B Cells
}

BioTechniques 23:518-524 (September 1997)

\author{
N. Chapal, M. Bouanani, M.J. \\ Embleton ${ }^{1}$, I. Navarro-Teulon, \\ M. Biard-Piechaczyk, B. Pau \\ and S. Peraldi-Roux \\ CNRS UMR 9921, Faculté de \\ Pharmacie, Montpellier, France; \\ ${ }^{1}$ Paterson Institute for Cancer \\ Research, Christie Hospital, \\ Manchester, England, UK
}

\section{INTRODUCTION}

The combinatorial assortment of immunoglobulin genes has permitted the creation of extremely large naive libraries (19). This approach has also been used to clone organ-specific highaffinity $\operatorname{IgG}$ autoantibodies (AAb) $(3,14)$. Information on heavy $(\mathrm{H})$ and light (L) chain variable gene usage of $\mathrm{AAb}$ obtained from random combinatorial libraries has been provided, in particular, by studies on autoimmune thyroid disease $(5,7)$. The majority of these human organ-specific $\mathrm{AAb}$ are derived from $\mathrm{VH} 1$ and $\mathrm{VH} 3$ gene families (15). Most evidence suggests that the $\mathrm{VH}$ and $\mathrm{VL}$ chain pairs isolated from these libraries are combined at random and do not reflect the pairings formed in vivo (15), which result from the combination between VH and VL chains expressed within the same B cell. Recently, Lagerkvist et al. (8) proposed an alternative approach to obtain human antibody fragments that retained the original VH and VL pairing by antigen-specific selection of single human B cells followed by cell culture and mRNA extraction.

In this study, we describe the use of the polymerase chain reaction (PCR) (16) to directly amplify the VH and VL genes within human B cells. This technique allows recombination between the original VH and VL gene segments expressed in each individual B cell and minimizes cross-recombination between B cells. Thyroid-infiltrating B lymphocytes (TIBL) of patients with Graves' disease were purified using anti-CD19-coated magnetic beads. After fixation and permeabilization of the $\mathrm{B}$ cells, mRNA was reverse-transcribed directly inside the cell. cDNA encoding for all VH and VL chains was subsequently PCR-amplified using specific nested primers. The two chains were linked within the B cells using the CreloxP site-specific recombination system of bacteriophage P1 (6), and two other rounds of PCR were performed. Using this system, a unique 800 -bp band, corresponding to a single-chain $\mathrm{Fv}$ (scFv) gene segment, was obtained. This result demonstrates that the construction of $\mathrm{scFv}$ fragments can be performed within B cells, completely bypassing the necessity to extract the mRNA. Furthermore, this procedure results in a repertoire that reflects the original pairing of $\mathrm{VH}$ and $\mathrm{VL}$, a critical feature for studying the autoimmune antibody repertoire.

\section{MATERIALS AND METHODS}

\section{Isolation and Purification of B Cells}

TIBL were obtained from patients suffering from Graves' disease. B lymphocytes were isolated from $10 \mathrm{~g}$ of thyroid tissue. The gland was minced with scissors and subsequently digested by using collagenase/dispase (Boehringer Mannheim, Meylan, France) at $25 \mathrm{mg} / \mathrm{g}$ of tissue, for $3 \mathrm{~h}$ at $37^{\circ} \mathrm{C}$. The digested tissue was then passed through a filter to remove remaining tissue fragments. After washing in phosphatebuffered saline (PBS; pH 7.2, supplemented with $100 \mathrm{U} / \mathrm{mL}$ penicillin and $100 \mathrm{mg} / \mathrm{mL}$ streptomycin), the cell suspension was incubated with $6.4 \times 10^{6}$ anti-CD19 magnetic beads/g of tissue (Dynal, Oslo, Norway) for $90 \mathrm{~min}$ at $4^{\circ} \mathrm{C}$ to purify the B cells. We obtained 5 $\times 10^{5}$ purified $\mathrm{B}$ cells from $10 \mathrm{~g}$ of thyroid tissue.

\section{Cell Fixation and Permeabilization}

Cells were fixed and permeabilized as previously described (4), except that 


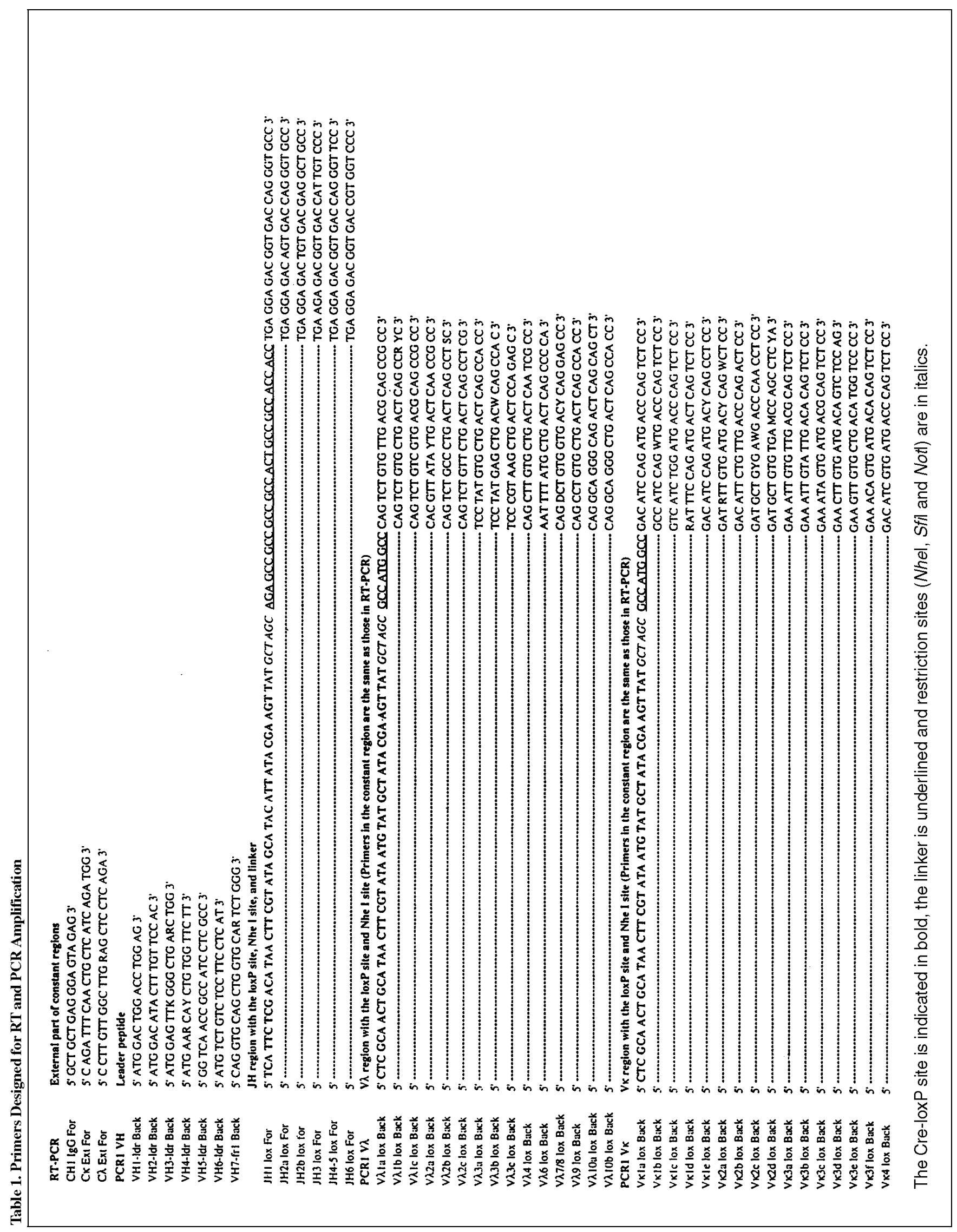


Table 1. Primers Designed for RT and PCR Amplification (Continued)

\begin{tabular}{|c|c|}
\hline $\begin{array}{l}\text { PCR2 } \\
\text { Cג Int For }\end{array}$ & $\begin{array}{l}\text { Internal part of constant regions (Primers in the leader peptide are the same as those in PRC1) } \\
5 \text { GAG GAS GGY RGG AAC AGA GTG AC } 3^{\circ}\end{array}$ \\
\hline CKInt For & 5' TGG CGG GAA GAT GAA GAC AGA 3 \\
\hline PCR3 & VH region with the $S n I$ site \\
\hline VHla Sfi Back & 5. GTC CTC GCA ACT GCG GCC CAG CCG GCC TTG GCC CAG GTG CAG CTK GTG CAR TCT GGG $3^{\prime}$ \\
\hline VHIb Sfi Back & 5 . \\
\hline VHIc Sï Back & 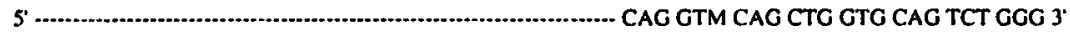 \\
\hline VHId Sfi Back & $s^{\prime}$ \\
\hline VHle Sfi Back & $s \cdot \ldots$ CAR ATG CAG CTG GTG CAG TCT GGG 3 \\
\hline VHIf Sï Back & $s^{\prime}$....... CAG GTT CAG CTG TTG CAG CCT GGG 3 \\
\hline VH2 Sfi Back & 5 . CAG RTC ACC TTG ARG GAG TCT GGT 3 \\
\hline VH3a Sti Back & 5 \\
\hline VH3b Sfi Back & 5 .... GAG ATG CAR CTG GTG GAG TCT GGG $3^{*}$ \\
\hline VH3c Sri Back & $5 '$..... GAG GTG CAG CTG GTG GAG TCT GCG 3 \\
\hline VH3d Sfï Back & 5 ' \\
\hline VH3e Sti Back & $5^{\prime}$.... CAG GTG CAG CAG CAG GAG TGA GGC 3' \\
\hline VH3i Sfi Back & 5 . CAG GTG CAG CTG GTC GAG TCT GGG 3 \\
\hline VH4a Sti Back & 5 . . CAG GTG CAG CTG CAG GAG TCG GGC 3 \\
\hline VHAb Sir Buck & s' \\
\hline VH4c Sfi Back & $S^{\prime}$ \\
\hline VHSa Sfi Back & 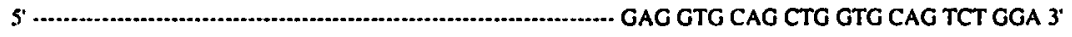 \\
\hline VHSb Sti Back & $s^{\prime}$......................... GAG GTG CAG CTG TTG CAG TCT GCA \\
\hline VHSc Sfi Back & $s^{\prime}$..... GAA GTG CAG CTG GTG CAG TCY GGA 3 \\
\hline VH6 Sfi Back & $5^{\prime}$ \\
\hline VH7 Sfi Back & JK region with the Not $i$ site \\
\hline JxI Not For & S. GAG TCA TTC TCG ACT TCC GGC CGC WCG TTT GAT TTC CAC CTT GGT CCC 3. \\
\hline JK2 Not For & 5 . .... WCG TTT GAT CTC CAG CTT GGT CCC 3 \\
\hline Jx3 Not For & 5 WCG TTT GAT ATC CAC TTT GGT CCC 3 \\
\hline JK4 Not For & 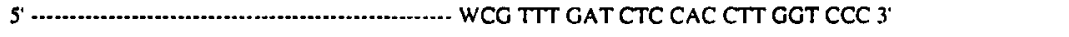 \\
\hline \multirow[t]{2}{*}{ Jxs Not For } & 5 ' \\
\hline & $J \lambda$ region with the Not 1 site \\
\hline JגI Not For & 5. GAG TCA TTC TCG ACT TGC GGC CGC CTA GGA CGG TGA CCT TGG TCC CAG $3^{\prime}$ \\
\hline$J \lambda 2 a$ Not For & 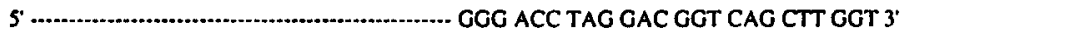 \\
\hline$J \lambda 2 b$ Not For & 5 CTA GGA CGG TCA GCT TGG TCC CTC 3 \\
\hline J24 Not For & 5 CTA AAA TGA TCA GCT GGG TTC CTC 3 \\
\hline J $\lambda s$ Not For & 5 - CTA GGA CGG TCA GCT CGG TCC CCT 3 \\
\hline J $26 \mathrm{a}$ Not For & 5 CGA GGA CGG TCA CCT TGG TGC CAC 3' \\
\hline Jג6b Not For & 5 CGA GGA CGG TCA CTT GGT CCA TGC $3^{\prime}$ \\
\hline 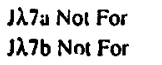 & 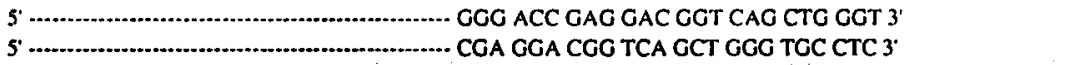 \\
\hline
\end{tabular}

The Cre-loxP site is indicated in bold, the linker is underlined and restriction sites (Nhel, Sfil and Notl) are in italics.

the $\mathrm{B}$ cells were bound to magnetic beads. Briefly, the purified B cells were washed three times in cold PBS, suspended in $50 \mu \mathrm{L}$ of an ice-cold $4 \%$ formaldehyde solution in $0.15 \mathrm{M} \mathrm{NaCl}$ and passed through a $1-\mathrm{mL}$ syringe equipped with a 20 - or 21-gauge needle to disperse clumps caused by aldehydeinduced cross-linking. Cells were incubated on ice for $1 \mathrm{~h}$ with shaking every $10 \mathrm{~min}$, pelleted by attraction with a magnet and suspended for washing in $50 \mu \mathrm{L}$ ice-cold PBS containing $0.1 \mathrm{M}$ glycine using the same syringe and needle. The washing step was repeated twice. The cells were permeabilized by suspending them in $50 \mu \mathrm{L}$ of $0.5 \%$ vol/vol Nonidet ${ }^{\circledR}$ P-40 (BDH, Essex,

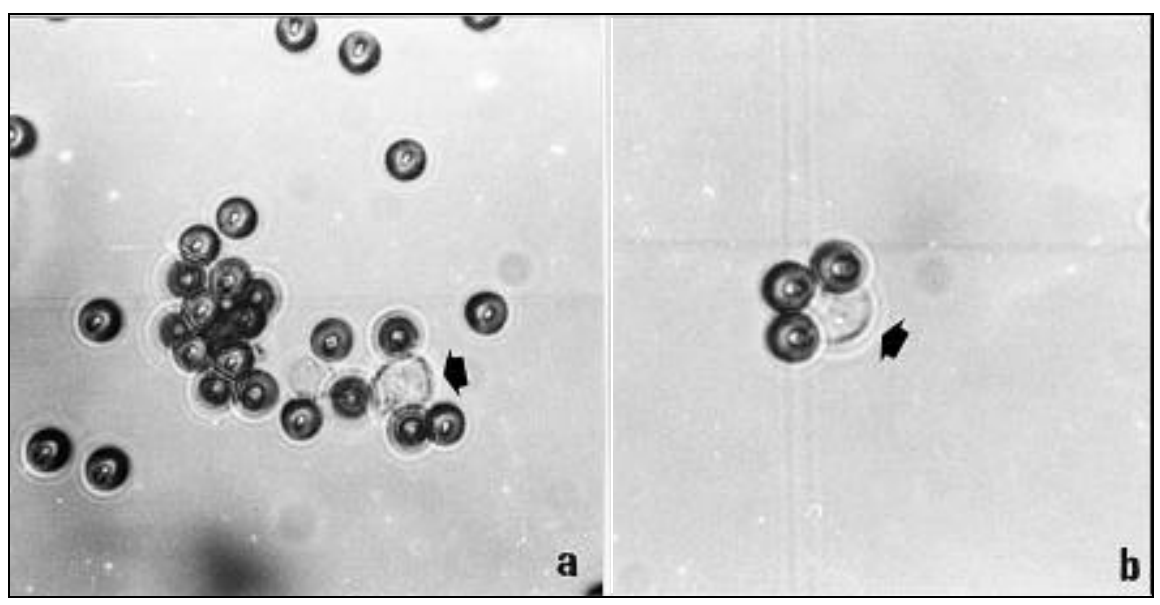

Figure 1. B cells bound to magnetic beads $(4.5 \mu \mathrm{m}$ in diameter) are visualized by rosette formation before (a) and after (b) PCR rounds. 
England, UK) in distilled water, using the same syringe and needle. After incubation for $1 \mathrm{~h}$ on ice with occasional shaking, the cells were washed three times in PBS-0.1 M glycine, resuspended using the same syringe and a 26-gauge needle to disperse the clumps visible under a light microscope (40X magnification). The cells were adjusted to a final density of $10^{7}$ cells $/ \mathrm{mL}$ in PBS-0.1 M glycine and used immediately or frozen at $-70^{\circ} \mathrm{C}$.

\section{Oligonucleotides}

Upstream primers were designed by analysis of the V BASE of human Ig genes [Medical Research Council (MRC), Cambridge, England, UK; World Wide Web address http://www. mrc-cpe.cam.ac.uk]. Four sets of primers were designed (see Table 1). The first one was used for the reverse transcription (RT) of mRNA of heavy and light chains into cDNA. It hy-

1) RT-PCR

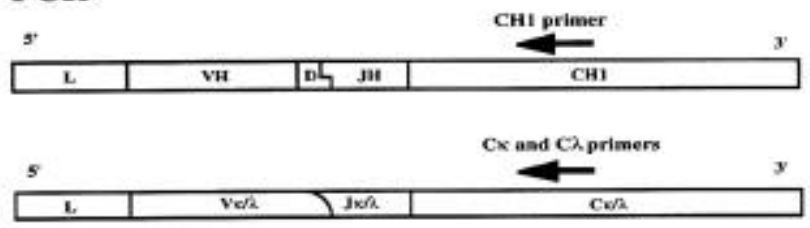

2) PCR 1
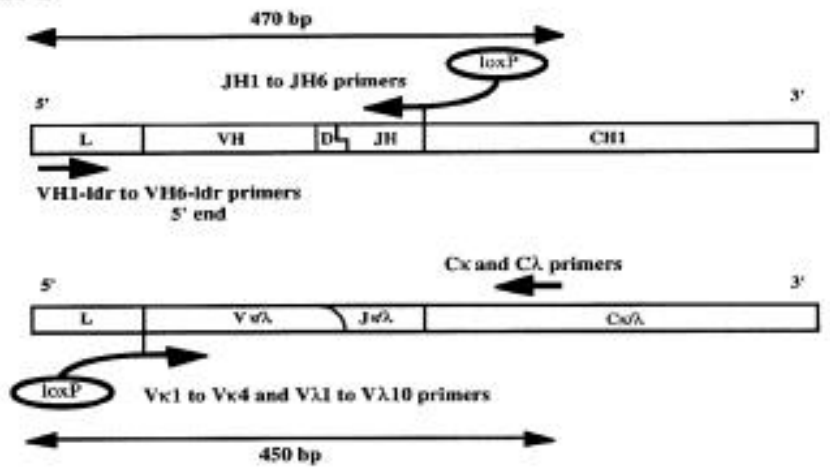

\section{3) Cre recombination and PCR 2}

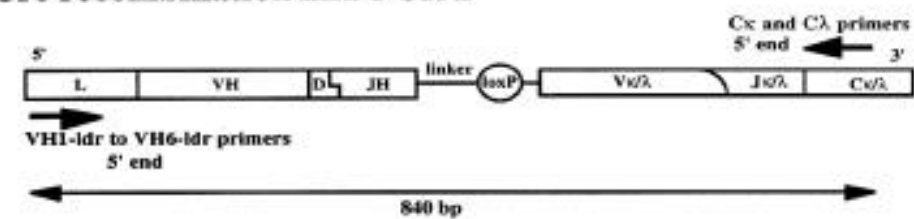

4) PCR 3

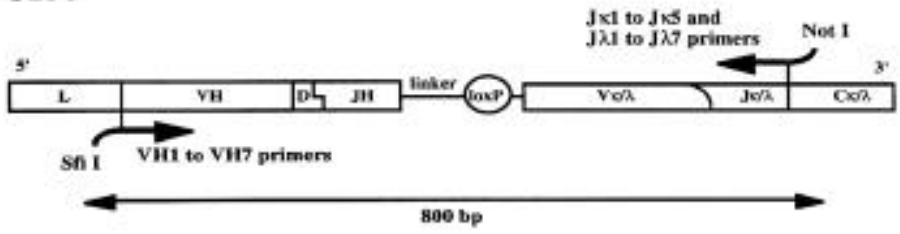

Figure 2. Schematic overview of the different steps leading to $\mathbf{s c F v}$ amplification. 1) cDNA synthesis, 2) first PCR for amplification of the VH and VL immunoglobulin genes, 3) a further round of PCR performed on the scFv product after Cre-recombination and 4) nested PCR and introduction of restriction sites. The hybridization position of primers are indicated by arrows, and the size of the amplified fragments are shown.

bridizes with the constant regions ( $\mathrm{CH} 1, \mathrm{C} \lambda$ and $\mathrm{C} \kappa)$. The second set of primers used for PCR1 allowed the amplification of $\mathrm{VH}$ and $\mathrm{VL}$ regions. They match with all the $\mathrm{VH}$ leader sequences and the $\mathrm{JH}, \mathrm{V} \kappa, \mathrm{V} \lambda, \mathrm{C} \kappa$ and $\mathrm{C} \lambda$ regions. These oligonucleotides introduce the loxP recombination site and the linker to obtain $\mathrm{scFv}$ fragments. The third set of primers was used after the recombination catalyzed by the Cre recombinase (1). The last set of primers was designed to limit the amplification to an $\mathrm{scFv}$ fragment and to introduce the restriction sites (SfiI and NotI) needed for the cloning step.

\section{RT, Cre-Recombination and PCR Amplification}

The reverse transcription was performed on the purified B cells $\left(5 \times 10^{5}\right.$ cells), using SUPERSCRIPT TM II RNase $\mathrm{H}^{-}$Reverse Transcriptase (Life Technologies, Cergy Pontoise, France). Crerecombination was performed according to the manufacturer's instruction (Novagen, Abdington, England, UK). After PCR amplification of the variable domain genes of the heavy and light chains, the Cre-protein mixture was added to the cell pellet to allow recombination between the loxP sites. We carried out the PCR in a total volume of $50 \mu \mathrm{L}$ containing $5 \times 10^{2}$ to $5 \times 10^{4}$ cells bound to anti-CD19-coated magnetic beads; 5 pmol of each primer were used as a mixture with $10 \mu \mathrm{M}$ dNTP, $5 \mu \mathrm{L}$ of HiTaq ${ }^{\mathrm{TM}}$ buffer and 2.5 U of HiTaq Polymerase (Bioprobe Systems, Montreuil, France). Thirty cycles of DNA amplification were carried out at $95^{\circ}(1 \mathrm{~min}), 65^{\circ}(1 \mathrm{~min})$ and $72^{\circ} \mathrm{C}(1$ min) for PCR1 and PCR2, and $30 \mathrm{cy}-$ cles at $95^{\circ}(1 \mathrm{~min})$ and $72^{\circ} \mathrm{C}(2 \mathrm{~min})$ for PCR3. The cells were pelleted using a magnet and washed twice with $100 \mu \mathrm{L}$ of PBS-0.1 M glycine after RT, Cre-recombination and each PCR amplification to eliminate all the amplification products that had diffused outside of the cells.

\section{RESULTS AND DISCUSSION}

\section{Isolation and Purification of B Lymphocytes}

The digestion of thyroid tissue from 
Graves' disease patient is a crucial step in the isolation of infiltrating B cells. McLachlan et al. (11) have shown that enzymatic digestion is required to separate the thyrocytes and to provide access to the lymphocytes that produce $\mathrm{AAb}$. We obtained the best yields of purification of lymphocytes from thyroid tissue after digestion for $2-3 \mathrm{~h}$ with collagenase/dispase $\left(5 \times 10^{5}\right.$ cells/10 g biopsy). After a shorter digestion period $(1 \mathrm{~h})$, only $1 \times 10^{2}$ cells were obtained, and digestion of thyroid tissue for more than $5 \mathrm{~h}$ did not lead to efficient CD19+ lymphocyte purification.

Anti-CD19 antibodies covalently bound to magnetic beads were used to purify the TIBL. As shown in Figure 1, isolated $\mathrm{B}$ cells can be clearly visualized by rosette formation. After cell fixation, permeabilization and three PCR steps inside the cells, the morphology of the cells did not appear to be modified (Figure 1b), suggesting that the B cells were unaltered.

\section{Design of Oligonucleotides}

To cover the widest possible range of VH and VL genes, we designed primers by analysis of available human sequences of antibody genes of the $\mathrm{V}$ BASE (MRC Cambridge). Eighty-four oligonucleotides were defined for their ability to amplify $\mathrm{V}$ gene families (Table 1). Primers were designed for RT-PCR and the three PCR steps.

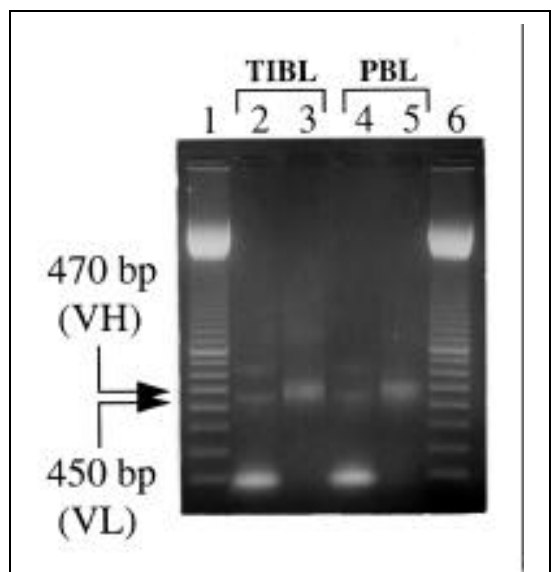

Figure 3. Amplification of VL and VH domains TIBL and PBL mRNA using a mixture of primers. Lanes 1 and 6, 100-bp ladder; lanes 2 and 4, VL domain (450-bp) from TIBL and PBL, respectively; lanes 3 and 5, VH domain (470-bp) from TIBL and PBL, respectively.
PCR1 amplified the VH and VL genes separately; the primers contained the loxP site necessary for Cre-recombination. PCR2 amplified a combination of VH/VL, and PCR3 introduced the restriction enzyme sites. The hybridization positions of the primers involved in each step of the PCR protocol are described in Figure 2. The loxP site nucleotide sequence used for the recombination between the $\mathrm{VH}$ and $\mathrm{VL}$ immunoglobulin genes was chosen on the basis of work reported by Waterhouse and coworkers (20).

As described by Campbell et al. (2), the primers used for amplification of the $\mathrm{VH}$ genes hybridize with the leader sequences of the VH1 to VH6 human gene families. To amplify the $\mathrm{VH} 7$ gene family, we used a primer that hybridizes with the first framework region. In contrast to the use of degenerate primers for PCR3 as described by other groups $(9,10)$, we designed new oligonucleotides that took into account the representation of all the $\mathrm{V}$ genes in each family $(18,22)$. This should favor representative amplification of the expressed $\mathrm{V}$ gene families during the PCR protocol. In addition, we used nested primers to reduce primer bias and to obtain specific amplification products.

The ability of these primers to amplify the VH and VL immunoglobulin genes separately was checked on TIBL and peripheral blood lymphocytes (PBL). Electrophoresis on a $1 \%$ agarose gel showed 470- and 450-bp
PCR products corresponding in size to $\mathrm{VH}$ and VL, respectively (Figure 3). We observed a second band of about $620 \mathrm{bp}$. By alignment of primers and CL genes, we found a second site of potential hybridization (65\% matching) of one primer that could be responsible for this amplification. The hybridization efficiency of oligonucleotides was tested on total RNA of PBL. Primers amplified the most represented $\mathrm{VH}$ families (VH1 and VH3 but also VH5 and VH7) (data not shown). The bias in the representation of $\mathrm{VH}$ subgroups obtained with our primer set corresponded to the frequency of gene usage in peripheral B cells (22).

\section{Validation and Optimization of In- Cell PCR}

As shown in Figure 4, the supernatant of in-cell PCR contained amplified material that had diffused throughout the cell membrane. Particularly, after the first PCR, 450/470-bp products were found in the supernatant (Figure 4, lane 2). Using a model of incell amplification of two hybridoma cell lines, Embleton et al. (4) previously showed that $70 \%$ of the total amplification products diffuse into the supernatant. For this reason, PCR products that had diffused outside of the cells were eliminated by washing the cells twice after each round of PCR, thereby preventing recombination of gene products from different cells as shown in Figure 4, lane 3. After PCR3, we

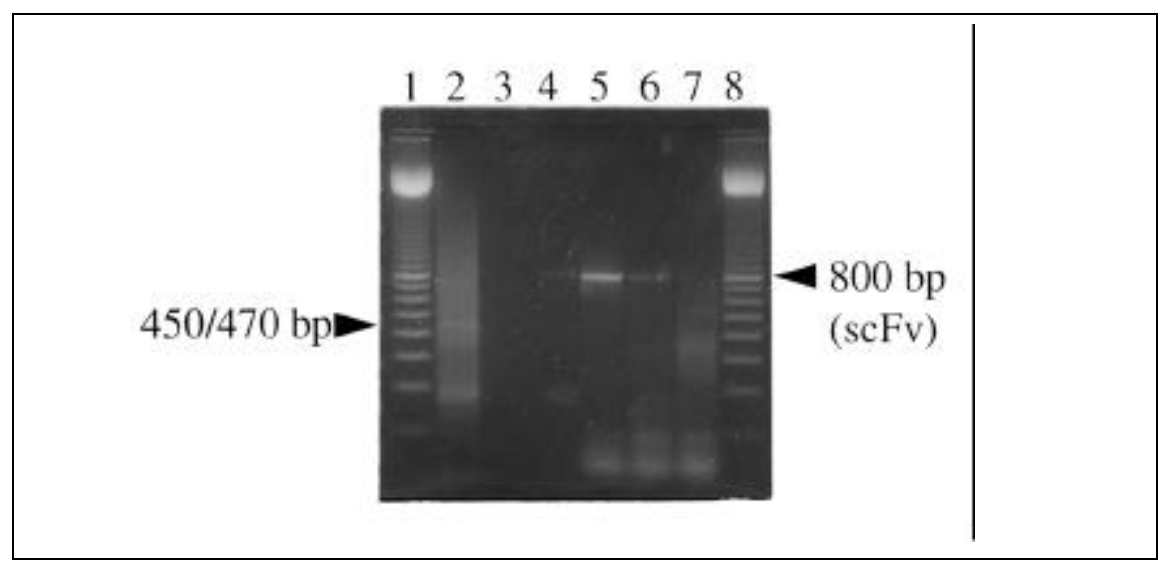

Figure 4. In-cell PCR. Lanes 1 and 8, 100-bp ladder; lane 2, PCR1 supernatant (450/470 bp); lane 3, PCR1 cell-pellet wash; lane 4, scFv 800-bp product of PCR3 performed on the washed cell pellet $(5 \times$ $10^{4} \mathrm{~B}$ cells); lanes 5,6 and $7, \mathrm{scFv} 800$-bp product of PCR3 performed on PCR2 supernatant from $5 \times$ $10^{2}, 5 \times 10^{3}$ and $5 \times 10^{4} \mathrm{~B}$ cells, respectively. 
observed an 800-bp PCR product on a $1 \%$ agarose gel (Figure 4, lanes 4-7), corresponding in size to $\mathrm{scFv}$ fragments resulting from amplification and combination within the B cells.

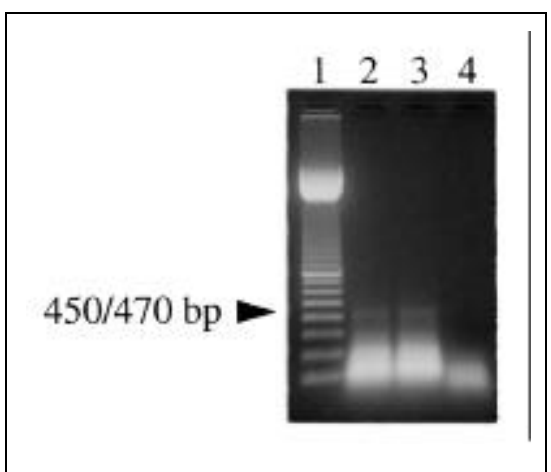

Figure 5. In-cell PCR control. Lane 1, 100-bp ladder; lane 2, PCR1 supernatant after amplification of VL genes only; lane 3, PCR1 supernatant after amplification of $\mathrm{VH}$ genes only; lane 4, Crerecombination, PCR2 and PCR3 performed on the mixture of VH and VL gene-amplified cells.
To confirm that the scFv products generated corresponded to pairing within the B cells, we amplified the $\mathrm{VH}$ and VL genes separately in different $B$ cells (Figure 2, lanes 2 and 3). The PCR1 cell pellets of the VH-amplified cells and the VL-amplified cells were subsequently mixed, and then Cre-recombination, PCR2 and PCR3 were performed. No product was observed after recombination, PCR2 and PCR3 (Figure 5, lane 4), indicating that the Cre-recombination in Figure 4 clearly occurred between VH and VL genes inside the same cell. Furthermore, Embleton et al. (4) showed in their 1992 paper, in which the in-cell PCR technique was described for the first time, that there was no cross-recombination when the technique was applied to a mixture of hybridoma cells lines, even when a 1:9 mixture of the two hybridomas was used. This finding was later confirmed using the Cre-loxP system to link the $\mathrm{VH}$ and $\mathrm{VL}$ genes, using the same hybridoma cell mixture (13).

PCR2 consisted of the amplification of $\mathrm{VH}$ and $\mathrm{VL}$ genes combined inside the cells. Thus, after PCR2, further amplification (PCR3) could be done either on the cell pellet or on the PCR2 cell supernatant. An 800-bp band, corresponding in size to an $\mathrm{scFv}$ fragment, was observed with both the cell pellet (Figure 4, lane 4) and the cell supernatant (Figure 4, lanes 5-7). The best apparent yield of amplification was obtained when the PCR3 was performed on the supernatant corresponding to an amplification product obtained from 5 $\times 10^{2}$ cells (Figure 4, lane 5), whereas PCR3 with $5 \times 10^{3}$ or $5 \times 10^{4}$ cells led to lower amplification (Figure 4, lanes 6 and 7). This indicates that the PCR efficiency is highly dependent on the number of B cells and apparently decreases as it does with increasing cells number. We think that the cells bound 
to the magnetic beads sediment to the bottom of the tubes during the PCR steps, thereby preventing the reagents from reaching all the cells. To improve PCR efficiency, we could dissociate the cells from the beads, but in this case, we would be deprived of a rapid way to wash the cells. Or, we could vortex mix the PCR mixture more frequently.

We report an in-cell PCR protocol associated with Cre-recombination applied to human TIBL. By this approach, we demonstrated the amplification and combination of $\mathrm{VH}$ and VL antibody genes within individual B cells, thus allowing natural VH and VL gene pairing. This approach offers a critical new alternative to the random combinatorial library technology. A major application of this technique is the cloning of polymorphic immunoglobulin genes to study $\mathrm{V}$ gene combinations of natural and autoimmune B cells. Furthermore, this in-cell PCR procedure can be performed with a relatively small number of purified B cells. The source of the B cells is critical for the successful cloning of organ-specific AAb. Fortunately, the TIBL population is enriched in autoimmune B cells secreting specific AAb. Thus, the antigen-specific selection of B cells can be avoided.

In autoimmune diseases, several reports have shown a biased usage of $\mathrm{V}$ gene families $(12,17)$ and a relationship between constant gene shift and the manifestation of the disease (21). The in-cell PCR described here, followed by phage display of antibody fragments, should allow access to the true autoimmune antibody repertoire in terms of gene usage and epitopic specificity.

\section{ACKNOWLEDGMENTS}

The authors wish to thank Drs. Greg Winter and Andrew Griffiths for pertinent advice on antibody engineering, Dr. Bernard Guerrier for providing the surgically removed tissue, Dr. Line Baldet for providing blood samples, Dr. Thierry Chardes for helpful discussions and Dr. Sharon L. Salhi for critical comments and help in preparing the manuscript. N.C. is a recipient of a fellowship from the MRES. This work was funded in part by the Elf Company.

\section{REFERENCES}

1.Abremski, K. and R. Hoess. 1984. Bacteriophage P1 site-specific recombination, purification and properties of the Cre recombinase protein. J. Biol. Chem. 259:1509-1514.

2.Campbell, M.J., A.D. Zelenetz, S. Levy and R. Levy. 1992. Use of family specific leader region primers for $\mathrm{PCR}$ amplification of human heavy chain region gene repertoire. Mol. Immunol. 29:193-203.

3.Costante, G., S. Portolano, T. Nishikawa, R.C. Jaume, G.D. Chazenbalk, B. Rapoport and S.M. McLachlan. 1994. Recombinant thyroid peroxidase-specific autoantibodies. II. Role of individual heavy and light chains in determining epitope recognition. Endocrinology 135:25-30.

4.Embleton, M.J., G. Gorochov, P.T. Jones and G. Winter. 1992. In-cell PCR from mRNA: amplifying and linking the rearranged immunoglobulin heavy and light chain Vgenes within single cells. Nucleic Acids Res. 20:3831-3837.

5.Hexham, J.M., J. Furmaniak, C. Pegg, D.R. Burton and B.R. Smith. 1992. Cloning of a human autoimmune response: preparation and sequencing of a human anti-thyroglobulin autoantobody using a combinatorial approch. Autoimmunity 12:135-141.

6.Hoess, R.H. and K. Abremski. 1984. Interaction of the bacteriophage $\mathrm{P} 1$ recombinase Cre with the recombining site loxP. Proc. Natl. Acad. Sci. USA 81:1026-1029.

7.Jaume, J.C., G. Constante, S. Portalano, S.M. McLachlan and B. Rapoport. 1994. Recombinant thyroid peroxidase-specific autoantibodies. I. How diverse is the pool of heavy and light chains in immunoglobulin gene libraries constructed from thyroid tissueinfiltrating plasma cells? Endocrinology 135:16-24.

8.Lagerkvist, A.C.S., C. Furebring and C.A.K. Borrebaeck. 1995. Single, antigenspecific B cells used to generate Fab fragments using CD40-mediated amplification or direct PCR cloning. BioTechniques 18:862869.

9.Marks, J.D., H.R. Hoogenboom, T.P. Bonnert, J. McCafferty, A.D. Griffiths and G. Winter. 1991. By-passing immunization. Human antibodies from V-gene libraries displayed on phage. J. Mol. Biol. 222:581-597.

10.Marks, J.D., M. Tristem, A. Karpas and G. Winter. 1991. Oligonucleotide primers for polymerase chain reaction amplification of human immunoglobulin variable genes and design of family-specific oliginucleotide probes. Eur. J. Immunol. 21:985-991.

11.McLachlan, S.M., C.A.S. Pegg, M.C. Atherton, S.L. Middleton, A. Dickinson, F. Clark, S.J. Proctor, G. Proud and B. Rees Smith. 1986. Subpopulations of thyroid autoantibody secreting lymphocytes in Graves' and hashimoto thyroid glands. Clin. Exp. Immunol. 65:319-328.

12.Pascual, V. and J.D. Capra. 1992. VH4-21, a human VH gene segment overrepresented in the autoimmune repertoire. Arthritis Rheum. 35:11-18.

13.Pope, A.R., M.J. Embleton and R. Mernaugh. 1996. Construction and use of anti- body gene repertoire, p. 1-40. In J. McCafferty, H.R. Hoogenboom and D.J. Chriswell (Eds.), Antibody Engeneering: A Practical Approach. IRL Press at Oxford University Press, Oxford.

14.Portolano, S., S.M. McLachlan and B. Rapoport. 1993. High affinity, thyroid-specific human autoantibodies displayed on the surface of filamentous phages use $\mathrm{V}$ genes similar to other autoantibodies. J. Immunol. 151:2839-2851.

15.Rapoport, B., S. Portolano and S.M. McLachlan. 1995. Combinatorial libraries: new insights into human organ-specific autoantibodies. Immunol. Today 16:43-49.

16.Saiki, R.K., D.H. Gelfand, S. Stoffel, S.J. Scharf, R. Higuchi, G.T. Horn, K.B. Mullis and H.A. Erlich. 1988. Primer-directed enzymatic amplification of DNA with a thermostable DNA polymerase. Science 239:487-491.

17.Siminovich, K.A. and P.P. Chen. 1993. B cells, immunoglobulin genes, and variable gene utilization by autoantibodies, p. 15-30. In C.A. Bona, K.A. Siminovitch, M. Zanetti and A.N. Theofilopoulos (Eds.), The Molecular Pathology of Autoimmune Diseases, Harwood Academic Publishers, Chur, Switzerland.

18.Tomlinson, I.A., G. Walter, J.D. Marks, M.B. Llewelyn and G. Winter. 1992. The repertoire of human germline $\mathrm{VH}$ sequences reveals about fifty groups of $\mathrm{VH}$ segments with different hypervariable loops. J. Mol. Biol. 227:776-798.

19.Vaughan, T.J., A.J. Williams, K. Pritchard, J.K. Osbourn, A.R. Pope, J.C. Earnshaw, J. McCafferty, R.A. Hodits, J. Wilton and K.S. Johnson. 1996. Human antibodies with sub-nanomolar affinities isolated from a large non-immunized phage display library. Nature Biotechnol. 14:309-314.

20.Waterhouse, P., A.D. Griffiths, K.S. Johson and G. Winter. 1993. Combinatorial infection and in vivo recombination: a strategy for making large phage antibody repertoires. $\mathrm{Nu}$ cleic Acids Res. 21:2265-2266.

21.Weetman, A.P., M.E. Yateman, P.A. Ealey, C.M. Black, C.B. Reimer, R.C. Williams, B. Shine and N.J. Marshall. 1990. Thyroid stimulating antibody activity between different immunoglobulin subclasses. J. Clin. Invest. 86:723-727.

22.Zouali, M. and J. Theze. 1991. Probing VH gene-family utilization in human peripheral $\mathrm{B}$ cells by in situ hybridization. J. Immunol. 146:2855-2864.

Received 2 October 1996; accepted 2 April 1997.

\author{
Address correspondence to: \\ Nicolas Chapal \\ CNRS UMR 9921 \\ Faculté de Pharmacie \\ 15 Avenue Charles Flahault \\ 34060 Montpellier Cedex 2, France \\ Internet:nicochap@pharma.univ-montpl.fr
}

